\title{
SYRIA'S DEFENSE AND SECURITY POLICY IN ADDRESSING THE ISSUE OF FOREIGN TERRORIST FIGHTERS (PERIOD 2011-2016)
}

\author{
Florensia Stevany Hanna \\ International Relations, Universitas Kristen Indonesia, Jakarta, Indonesia \\ florensiastevany@gmail.com
}

\begin{abstract}
The researcher is interested in researching the phenomenon of Foreign Terrorist Fighters (FTF) more in-depth. Why is Syria became the main objective of these terrorist fighters because the issue of FTF in Syria is still rare to get researched? The study aims to analyze the phenomenon of Foreign Terrorist Fighters why go to Syria and how the Syrian government's response to this issue. This study uses FTF theory or concept to explain the FTF phenomenon, also defense and security policy to explain what procedure is used by Bashar alAssad in the handling of FTF issues. What will be discussed in this research is on the implementation of Syria's defense and security policy in handling the issue of Foreign Terrorist Fighters, as well as how it impacts on Syria's security itself. The results of this study suggest that the Syrian government has had a positive impact in implementing its policy for Syria's protection. The most significant is the reduced number of FTFs coming to Syria. The success of recaptured cities controlled by the previous FTF and more territorial supervision tightened.
\end{abstract}

Keywords: Syria's Defense and security policy, the Syrian government, terrorism, FTF

DOI: 10.33541/sp.v19i2.1647

Sociae Polites : Majalah IImiah Sosial Politik

Faculty of Social and Political Science, Universitas Kristen Indonesia

ISSN 1410-3745 print/ ISSN 2620-4975 online

Volume 19, Number 2 (July - December 2018)

Pages 92-104 


\section{Introduction}

One of the real significant threats in human life is the threat of terrorism. The risk of terrorism not only originated from local or domestic terrorists but more dangerous, the Foreign Terrorist Fighter. The FTF can be interpreted as a terrorist alien warrior who departs abroad to fight alongside other militias from various countries to help the struggle of a particular, extreme militia group. The inclusion of FTF to Syria in the amount raises a concern for the Syrian government. On one side, opposition against the government of Bashar due to the outbreak about people's protests against the Bashar al-Assad regime, caused by discontent of the people for his leadership during the presidency. This event is called the Arab Spring. On the other hand, Assad is struggling against terrorists, namely ISIS. Such conditions make Syria very vulnerable to the inclusion of FTF from various countries and cause surveillance or security against the boundary/region to be minimal and make Syria easily entered by the FTF.

The study aims to analyze what factors influence the FTF to come to Syria and how Syria's defense and security policies handle the FTF and its impacts on Syria itself. Referring to Theodore J. Stein's defense and Security Policy theory (Stein, 2001), the study analyzed how the Syrian government could restrict the inclusion of FTF to Syria. The purpose of this Syrian defense and security policy proved to reduce the number of FTF coming into Syria. It successfully recaptured several cities in Syria previously ruled by foreign terrorist fighters from various groups, done by dispatching troops and weapons from Russia and Iran, as well as tightening surveillance in the Syrian border region.

The research methodology used in this research is a qualitative approach. The study intends to understand the phenomenon of what is experienced by subjects such as perception, motivation, action, holistic and thorough descriptions in the form of words and language in a specific context that is natural by utilizing various natural methods.

\section{The Phenomenon of Foreign Terrorist Fighters}

An intelligence analysis from Azerbaijan, Jahangir Arasli, stated that foreign fighters are volunteer fighters who do not have a clear relationship with the territory of armed conflict that is in progress but bound by the sense of his obligation of the Muslim worship (Alex P. Schmid, 2015). This definition indicates that they (foreign terrorist fighters) who go to the conflict in the Middle East, actually has no relation to the current conflict, but only because of the sense of bonding as fellow Muslims. These FTFS are individuals who depart from their country and go to other countries, as well as join other radical groups or militias and also perform terror acts that generally involve armed conflicts. The FTF went to Syria and joined the militant group of Islamic State of Iraq and Syria (ISIS) Most of the 15-35-year-old youth motivated by extremist ideology, the Salafi Jihad so that it made the youth the most vulnerable group to the extremism, radicalization, and recruitment as the FTF (Ki-Moon, 2015).

Since the ruling system was declared in the middle of 2014 in August by the ISIS leader himself, Abu Bakr al-Baghdadi, there were about 6,000 waves of recruitment of new fighters. And then it grew to about a thousand soldiers who joined ISIS in the following months, with such a war, Jihaddan, and other activities also increasing. Nearly half of all countries with predominantly Muslim and non-Muslim countries now produce foreign fighters to fight in the territory of the Jihad war. A Palestinian journalist named Abdel Bari Atwan, who visited ISIS in late 2014, said the number of jihadists in Syria and Iraq 
increased the following year.

Table.1 Number of FTF Joining ISIS in 2011

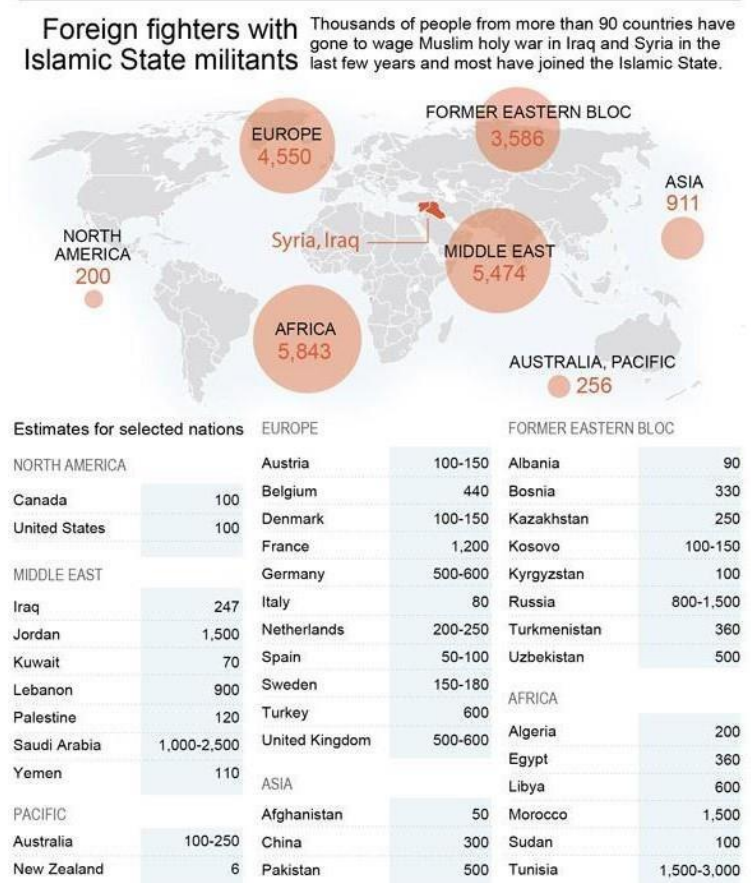

Source: The International Centre for the Study of Radicalisation and Political

Violence, 2011

Above there is a picture showing the number of foreign terrorist fighters who came to join ISIS in the year 2011. About 2,500 soldiers come from Western countries, including some E.U. Member States, the United States, Canada, Australia, and New Zealand. It showed on the table that the majority of foreign terrorist fighters are from the Middle East. Also, according to figures collected by the Soufan Group, between 27,000 to 31,000 people from 80 countries including women and children who's not usually involved in the conflict have traveled to Syria and Iraq to join the state and other Islamic extremist groups to fight in the region at the end of this, the majority of foreign terrorist fighters come from Western European countries. Also, some American citizens are known to have joined and fought in Syria.

The reason that these people join the Islamic State or other extremist groups depends on where they originate. A research institute based in Lebanon, Quantum Communication researches by interviewing 49 foreign terrorist fighters in Syria and Iraq. Quantum Communication Researchers used a psycho-contextual analytical technique (Pshycho- contextual) developed by Canadian psychologist Marisa Zavalloni to determine the personal motivation or characteristics of foreign terrorist fighters (Tucker, 2015). There are nine categories of why foreign terrorist fighters join the ISIS or other extremism groups, namely:

- Seekers Status aims to increase their "social status." Fighters motivated by this goal generally driven because of money and to get recognition from people around them

- Identity Seekers: This usually happens to individuals who have fragile feelings, such as being vulnerable or feeling isolated or alienated. These individuals often 
feel like "outside people" in their previous environment; they tend to be aloof, feeling exiled, not regarded by those around him.

- Revenge Seekers: Individuals who consider them to be part of the group being pressured by Western countries or others, thus making them want to avenge what happens to them.

- Redemption Seekers: Those who go to Syria or Iraq and join ISIS for believing it will justify or permit them and also correct their previous mistakes or sins.

- Responsibility Seekers: Essentially, people who have joined or endorsed ISIS or other radical groups because to provide material or financial assistance to their families in their country or place of origin.

- Thrill Seekers: Those who join ISIS generally to go on an adventure or find a new sensation, usually happening to those who love new challenges.

- Justice Seekers: They respond to a thing they consider being an injustice. These fighters joined the radical group when the perceived justice was no longer there or lost. Usually, they feel they have been mistreated again by the environment or the government of the country.

- Ideology Seekers: Individuals like this, in general, want to impose (impose) their views or understanding of the teaching of Islam to others.

- Death Seekers: People like this may suffer trauma or feel a profound loss, so assuming death is the only way out with a martyr's reputation.

The ideology adopted by foreign terrorist fighters is Salafi jihadism. SalafiJihadi is the term gives to Muslims who enjoy a similar view to the Salafiyyun (Reinares, 2017). Salafism, as a strict understanding of the Quran, brings its followers to believe that liberal democracy is unlawful or forbidden from an Islamic perspective. This ideology essentially allows a person to overthrow their government to achieve their goals, especially to build a system of authorism and spread Salafi-jihadism to all Muslims of the world. To achieve this goal, they carried out military training that could increase their ability to establish military strategy and fight against the enemy (Damayanti, 2012).

\section{Foreign Terrorist Fighters Objective}

The increasing number of FTF, increase in action against terrorism conducted by the government. However, no matter how many counter-terrorism actions are committed, as long as there is an appeal or call for individuals to go to Syria or Iraq, they will most likely continue. One of the interviews conducted by the CBS news agency reporter, Clarissa Ward, said that they (foreign terrorist fighters) who came to Syria driven by a sense of enthusiasm and curiosity about what they saw or witnessed online, usually like videos via YouTube or other Internet media. In general, they wanted life under Islamic Sharia law, so they joined the extremist groups that existed there, ISIS. The creation of the whole country is the expectation of the FTFs.

Based on the categories of why a person becomes an FTF and joins a radical extremist group delivered by Tucker, it states that some people participate in the FTF because it seeks to seek identity, money, status, revenge, justice, some for ideology and so on. Many young men in western countries whose lives have no purpose or do not feel like part of their environment. The ISIS Group offers to the youth or to this new recruitment to have experience and be part of something big when they go to Syria or Iraq. When they go there, they will accept as brothers or sisters who are fighters or 
heroes.

\section{Access Traveling to Become FTF}

The trip that an FTF will take to join the group of ISIS can happen in a variety of different journeys; in other words, there are various routes to reach the Khalifah.

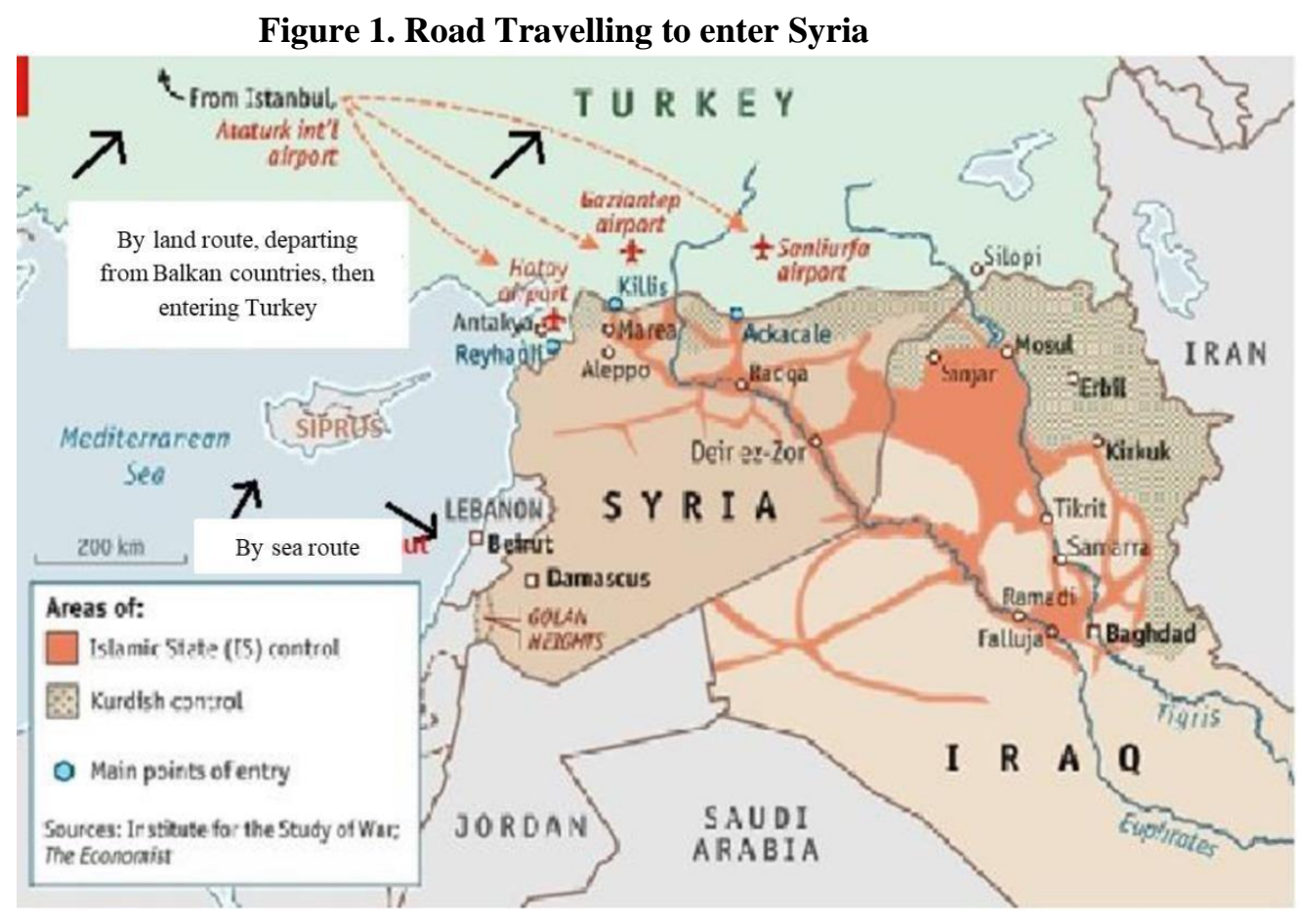

Source: The Economist

The routes traveled by the fighters who are going to Syria or Iraq often need a combination of land, air, and sea travel routes. But they all had one element of the same purpose, which was the journey they would end up in Turkey, where the hypnotism could achieve by crossing the borders of the region directly into Syria. Like the map above, the point of entry to Turkey is three, namely, Reyhanli, Killis, and Ackacale. The way to reach Turkey has changed, can be achieved in various ways, but the country remains the most common route to enter the areas ruled by ISIS, especially since the group announced itself as a caliph with its headquarters in Rakka, Syria. For air routes, most people who go from America and certain European countries, to be able to get to Turkey, is easy to book a plane ticket.

Sea routes are a much more effective way for potential fighters to get to Turkey without being detected, but the risks are higher. Aspiring fighters can use the usual sea lanes to trade or routes commonly used by immigrants to flee their country to Europe. Jytte Klausen, a professor of the International Cooperation at Brandeis University and founder of Western Jihadism Project, said that the journeys made by prospective fighters disguised as refugees are not a new ISIS tactic, but many routes to that which will not require much effort (Masi, 2015).

Then for those who do not benefit from the E.U. border strategy because they are not the holders of passports of E.U. member States or perhaps who already registered in the prohibition of flying or lack of correct documentation, may choose to travel longer through 
the land route. This route can use by fighters departing from Europe or North Africa. The most common tracks for soldiers leaving from eastern or Western Europe are by driving or taking a bus through the Balkans to the Bulgarian border and entering the northern region of Turkey, or also able to drive to Greece and use a land junction to Turkey.

Thus, the growing security in the borders of a country, the easier it will be for recruits to enter Turkey and then cross over to Syria, both through air, land, and sea lines. Then it is currently being proclaimed to take stricter security measures by many countries to prevent foreign fighters from joining forces with such radical groups as ISIS.

\section{Syria Condition}

Syria, also known as the Syrian Arab Republic, is a country in the Middle East, bordered by Lebanon and the Mediterranean Sea to the west, Turkey to the north, Iraq to the east, Jordan to the south, Israel to the southwest. The capital and largest city in Syria is Damascus. Syria became an independent state in 1946, having been mandated by the French. The current head of state of Syria is Bashar al-Assad, who is the son of Hafez alAssad, the president of Syria who took office on 22 February 1971 and ruled until June 2000 (Subekti, 2014).

In his post-inauguration speech, Bashar al-Assad gave the promise to make Syria more modern and democratic. However, the reality is not so. Syria, under the leadership of Bashar al- Assad was experiencing the inequalities caused by Assad's wealth gaps. Volker Perthes, a Syrian specialist who is the head of the German Institute for International and Security Affairs, said that in the minds of his opposition, Bashar failed to implement his promise. He said, when the government is challenged or protested by the demonstrators, the regime will always act violently, so there is protest. The way used to damper it is violent so that people know that this is dangerous (MacFarquhar, 2011).

The abdications occurring in Syria make the governing regime accused of preparing and using chemical weapons for the rebels and other civilians. This statement asks by the United States and its allies. However, this was disputed by Syria's deputy foreign minister, Walid al-Moallem, who asserted that neither the Syrian government nor the army would and would not use any chemical weapons in any form, even against terrorists targeting Syrian people (al- Frieh, 2017).

The crisis in Syria worsened when it topped the Arab Spring in Syria. This Arab Spring phenomenon has been the trigger of the political upturn to the prolonged conflict in Syria, but this phenomenon is not the only cause of conflict in Syria. Still, it is also essential to be able to understand the situation and conditions that become the background of the emerging political upturn in the country. It can see from Syria's authoritarian system of government. Based on The Democracy Index released by The Economist in 2010, Syria has relatively low points. It can see in the following table. 
Table 2. Syria-Level Democracy Indicator year 2010

\begin{tabular}{|c|c|c|c|c|c|c|}
\hline Rank & $\begin{array}{c}\text { Ove } \\
\text { rall } \\
\text { Score }\end{array}$ & $\begin{array}{c}\text { Electoral } \\
\text { Process } \\
\text { and } \\
\text { pluralism }\end{array}$ & $\begin{array}{c}\text { Functioning of } \\
\text { Government }\end{array}$ & $\begin{array}{c}\text { Political } \\
\text { Participation }\end{array}$ & $\begin{array}{c}\text { Political } \\
\text { Culture }\end{array}$ & $\begin{array}{c}\text { Civil } \\
\text { Liberties }\end{array}$ \\
\hline 153 & 2.36 & 0.00 & $\begin{array}{c}1.7 \\
9\end{array}$ & $\begin{array}{c}1.6 \\
7\end{array}$ & 6.88 & $\begin{array}{c}1.4 \\
7\end{array}$ \\
\hline
\end{tabular}

Source: Economist Intelligence Unit's Index of Democracy, 2010

The index, which was released by The Economist, shows that Syria ranks is 153 and classified in a group of countries with authoritarian regimes, can see in the indicator listed above, which is a reference in the democracy level of a nation. In addition to being classified as an authoritarian state, Syria is also one of the countries with a relatively high level of corruption. can see in the data released by Transparency International -Corruption Perception Index" From 2011 (International, 2011), which places Syria in the 129 positions of the 176 countries in the world. In the year 2016, the Syrian situation changed to 173 from the previous location of 129 (International, 2016). This sequence shows that the corruption that occurred in Syria is very high. Various negative depictions have displayed, not notwithstanding the hegemony of the Assad regime and the Ba'ath Party in Syrian politics dynamics.

\section{a. Condition of Syria after the Arab Spring}

Demonstration action as a real manifestation of Arab Spring occurring in some countries in the Middle East has different levels, and not all demonstrations make to have an impact on the development of political change in the region. There is the number of key or facts of Syrian conditions after the Arab Spring, which is according to the U.N. records, at least more than 250,000 casualties that fall due to conflicts between Governments and opposition, thereby making large numbers of violence against humanity (Khabieh, 2016). Then, since the Arab Spring, more than 11 million Syrian residents were forced to abandon their residence due to civil war and go to another country to seek better circumstances, including about four million Syrians now becoming overseas refugees. Their destination is the neighboring countries of Syria, such as Turkey, Lebanon, and Jordan.

More than 10,000 Syrian citizens had gone to Europe and often risked their lives in their process of entering the European countries. That is because Syrian refugees who came to Europe had mostly suffered rejection from the country's governments, and even those who force to be unable to enter the country, so the Syrian refugees became homeless. According to the Syrian Network for Human Rights, about 65,000 Syrian citizen's arrest by government authorities, and others had imprisoned for protesting against the government. Then other facts include the emergence of armed radical groups, including ISIS and Jabhat al-Nusra, who participated in attacking civilian areas, kidnap civilians, and even killed.

\section{b. The entry of Foreign Terrorist Fighters in Syria}

Many who assumed war in Syria are happening today is the "small show" Third World War. One reason is that there are so many alien forces involved in this war. Syria is 
like a field for the power of Middle Eastern countries such as Saudi Arabia, Qatar, Turkey, Iran, and the coalition of Western nations. That demands the decline in the Assad regime drive-by soldiers, the Syrian Army, and the Syrian National Council (Syrian National Council).

The Arab Spring phenomenon is happening in some countries in the Middle East, but the foreign FTF coming to the region has a purpose, namely to go to Syria. This poor Syrian state provides an opportunity for terrorist fighters to strengthen the terrorist groups he supports and can give them the freedom to launch their international military assault plans. The more complex the Syrian crisis is, there is one clear thing, the longer the conflict or crisis progresses, the higher the threat that exists. The harder it is for Syria itself and even other countries to fight the threat of terrorism.

This conflict in Syria becomes a magnet for individuals to flock to and enhance the battle. Foreign fighters are coming, entering through the Northern line that is Turkey and then entering Syria. The growing number of terrorist fighters coming to Syria from 2011 can say to be admirable because of the high enough. In the year 2011, there are more or less 1,200 soldiers who came, and in 2012 become more than 3,500, then in 2013, more than 8,500 , it increased again to 18,000 in 2014 and became more than 25,000 in September 2015 (Schmid, 2015). Since the declaration of the Khalifah in June 2014, there were at least a thousand foreign fighters each month joining the ISIS group. According to data gathered by the Soufan Group, between 27.000 until 31.000 people, including women and children who are not generally involved in the conflict, have traveled to Syria and Iraq to join countries and other Islamist extremist groups of battles in the region. (Kirk, 2016).

The opposition group in Syria itself consists of several groups, namely the level of government that is the defectors of the government and also as the inner rebels. There was also opposition who joined the rebel group to defend civilians who continued to oppressed. Also, there is cooperation with terrorist alliances. But all had one common goal, to overthrow the Bashar al-Assad regime. There are several groups of opposition in Syria examined in this article (Jane, 2013), i.e., the Free Syrian Army (FSA) or the Syrian free soldier formed in August 2011, created by a former colonel in the Syrian Air Force, Riad Mousa al-Assad. Then there was the Martyr of Syria Brigade affiliated with the FSA. The Martyr of Syria Brigade has a range of fighters as much as 7,000. The group was formed at the end of 2011 in Idlib and operated around western Syria. Unlike other Islamic groups, however, the Martyr of Syria Brigade does not adhere to specific ideologies. There is also the Ahrar Souriya Brigade (Free Men of Syria) operating under the FSA, founded by Col Qasem Saad al-Din, an Air Force pilot from Rastan, Syria.

Subsequently, there was also a jihadist group as opposition in Syria. That is the creepiest group in Syria (Pinto, 2016), the Jabhat al-Nusra, which is a branch of the alQaeda group created in 2011, headed by Abu Mohammad al-Julani and has fighters around 15,000 to 20,000. The group expressed its existence in January 2011 and has since emerged as one of the most effective rebel forces. The second is the Islamic State of Iraq and Syria (ISIS) or the Islamic State of Iraq, and the Levant (ISIL) is a jihadi group of al-Qaeda branches as well. Abu Bakr al-Baghdadi led the group. The group claimed to follow Islamic fundamentalists, Wahabi's doctrine of Sunni Islam. ISIS or ISIL is also known as Daesh. That group most enthused the FTFS to come to Syria and identifies as the cruelest group, which did not hesitate to kill anyone who does not fit the pattern of their minds. ISIS aimed to establish the Islamic State and apply Sharia law throughout the country. Mostly the group used cruel ways to justify (justify) their deeds. 


\section{Syria Defense and Security Policy}

In an interview with Phoenix T.V., Assad declares Syria's defense and security policies requesting military assistance to Russia and Iran as well as willing to cooperate with any country that would genuinely help Syria. Assad state, the opposition referred to the Syrian government here is anyone who rebelled against the government regime. Mostly anyone who commits armed resistance to the government is considered a terrorist.

As Barry Buzan says in his book New Patterns of Global Security in the Twentyfirst Century (1991), the security issues will be difficult if it is a single state problem but also requires regional and international coordination. State security is also an essential aspect of the national interests of a country that must be fought and maintained. For the Assad president, the safety of his people and state is the main thing. It is on this basis that Syria sought military aid to Russia and Iran to defend its country's sovereignty from the threat of opposition groups. Russia was the most substantial and most significant ally of Syria in providing military aid to the Assad government regime. Russia has vital economic and military interests in Syria, one of which is like the rank of Mediterranean naval forces in Tartus determined to be defended by Russia (Park, 2017). Another reason that Russia assists the Syrian government against its opposition is merely to prevent the spreading of terrorism that can harm Russia itself. Russia wants to move freely in dealing with terrorism among the Muslim minority in his country. The Iranian then supported the government regime and provided support, stating that other parties who attempted to lower Bashar al-Assad were the sabotage of foreign parties, namely the U.S. and its allies.

Iran's involvement in the conflict occurred in Syria was a demand from Bashar alAssad, which was one of Syria's policy of Syrian defense and security in maintaining its country's sovereignty. Iran participated in the civil war in Syria in 2013. Iran assisted the Assad regime by supplying several units and military personnel. Hezbollah fighters supported by the Iranian government have taken on the role of fighting the Assad regime since 2013 (Saul, 2014). As the Civil War entered the fourth year, Iran had increased its support to ASSAD by providing an elite team to collect intelligence and train its troops.

Further support, along with the delivery of ammunition and equipment from Russia, can assist President Assad in defending his country's sovereignty and power at the time the gunship or army has no more superiority in the war. Assad received the benefit of spreading Iranian troops to other Syrian territories. The Syrian government was also assisted by Hezbollah's group to seize Buwayda's village and end the rebel resistance around Qusair's town was a new success for President Assad (Karouny, 2013).

The Russian military began admission to Syria first in September 2015 in Homs after receiving a request from the Syrian government to assist in the army against the rebel and terrorist groups (McDonnell, 2015). Russian fighters launched their airstrikes against the opposition that had the target in Syria. The Russian government said it was done to support the government of Bashar al-Assad and targeted the terrorist fighters ISIS who controlled most of the Syrian regions as part of the fight against terrorism. After this operation began, the Russian authorities said that despite the opposition to the terrorist, other Russia's goals were to assist the Syrian government in reclaiming its territory from various anti-government opposition groups. In the Russian, first attack, the area that was designated by Russia was a territory ruled by rebel factions struggling for the FSA group as well as the fortress of Al-Nusra (Aljazeera, 2015).

In keeping with the security of his country, the Syrian foreign minister, Walid alMoallem said that his country is willing to cooperate with the international community that 
exists both regionally and internationally in the fight against opposition groups, especially ISIS or ISIL. The Syrian government sees the groups of ISIS and al-Nusra and other jihadi groups are more dangerous than the Taliban or al-Qaeda. Then in December 2015, Russia was reportedly preparing to expand its military operating area in Syria by opening air-ships around Homs for gunship helicopters and troops that were ready to engage in its mission. Pictures are showing the Russian military and also parts of Syria ruled by the opposition in 2015:

Figure 1. Pro and Anti-Government Group Regime Mapping

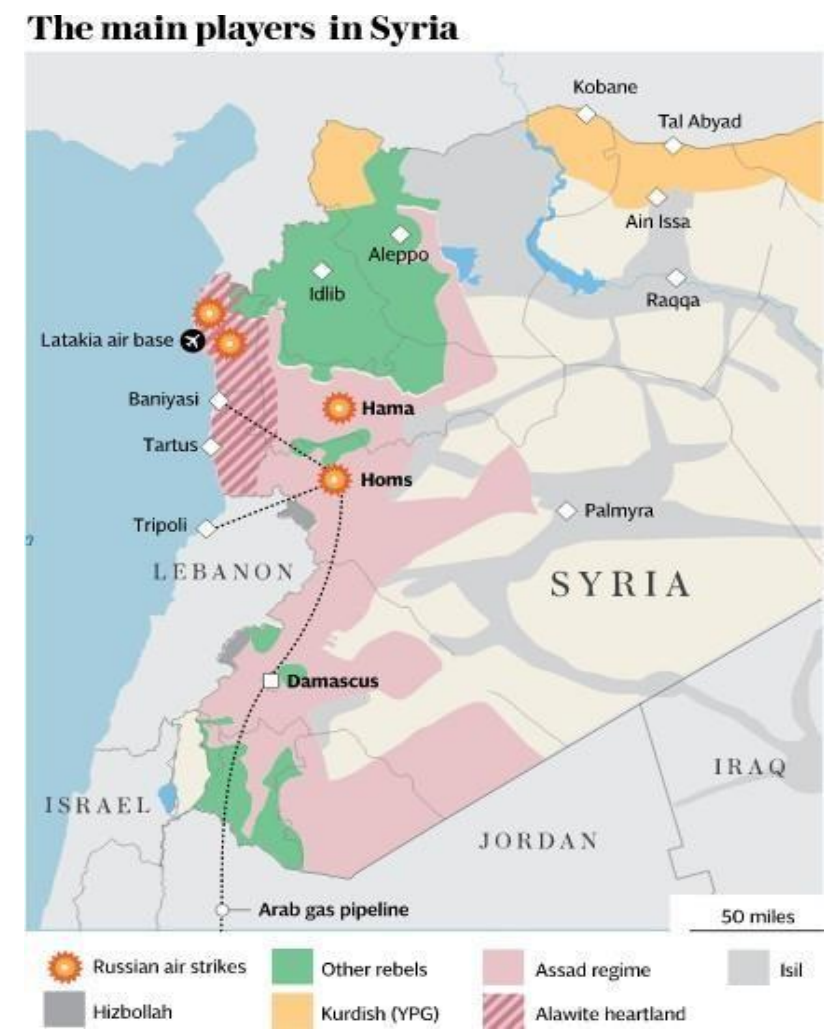

Source: The Telegraph

The air aid of the Russian Air Force in the region was to assist Bashar al-Assad's troops in conducting attacks on Palmyra and al-Karyatayn. They were under the control of the ISIS terrorist group. Russia also increased the number of aircraft to 100 units to meet the needs of the Syrian army. Syria got the help of a large number of double-launch rocket systems and flamethrower guns (Parfitt, 2015). In theory, Russia helped Syria to fight ISIS, but in practice, Russia also attacked other anti-Assad groups that were partly supported by Western countries. The reason Russia would help Assad because the government feared the potential posed by the Syrian conflict would have impacted the growing number of Muslims in Russia. It was also because Russia did not want the influence of the United States and its allies to be hegemony in the Middle East.

The success of Russian aid in maintaining the security and defense of Syria proved when Palmyra was successfully recaptured by the government, which was previously under the control of the ISIS fighters in March. Palmyra successfully recaptured after Syrian fighter jets aided by Russian fighter jets bombarded ISIS bases in the city. ISIS 
fighters are escaping, and some of the vehicle convoy carrying ISIS guns destroyed in the attack. With the Russian presence making Assad's security guarantees, it was within the six months of the rebel that took place in Homs, Hama crushed, and then the ISIS-controlled Palmyra had been blockaded since the middle of 2016.

The ASSAD Support Group conducted an all-out assault on the rebels and other Syrian opposition, launching the air bombings in the surrounded East Aleppo and missile attacks from a Russian aircraft carrier that stationed off the coast. Here's a table showing what help Russia and Iran has given to Syria to deal with FTF issues:

Table 3. Russia and Iran gave military assistance in 2015

\begin{tabular}{|c|c|c|}
\hline $\begin{array}{c}\text { No } \\
\cdot\end{array}$ & Russian & Iran \\
\hline 1 & 1000 more Russian troops & Personnel or military forces \\
\hline 2 & $\begin{array}{c}\text { Four Mi-24 helicopters and one MI-8 } \\
\text { helicopter }\end{array}$ & $\begin{array}{c}\text { Elite Team and military } \\
\text { intelligence }\end{array}$ \\
\hline 3 & $\begin{array}{c}\text { 35 Sukhoi Su-24 bomber aircraft and Jet } \\
\text { Su-25 }\end{array}$ \\
\hline 4 & $\begin{array}{c}\text { Black Jack's Tu-160 bombers and } \\
\text { Tu-95 Bear }\end{array}$ \\
\hline 5 & Flamethrower weapon, TOS-1 & \\
\hline \multicolumn{2}{|c|}{ Source: The Times U.K., 2015 } \\
\hline
\end{tabular}

In addition to military assistance, Russia also provided humanitarian aid to about 4,000 Syrian citizens, namely medicine aid, 20 tons more food supplied by the United Nations through the Russian Army (Mengjie, 2016). This assistance gives to Syrian citizens in a conflict environment such as Aleppo, Hama, and Deraa. With military aid provided by Russia and Iran, it proved to have a significant impact on the Syrian government. That can be seen by some towns that were initially ruled by insurgents or opposition, now already taken back by the government, such as Palmyra, Kobani, Dabiq, Tal Abyad, al-Qaryatayn, Homs, Aleppo.

Through additional troops from Russia and Iran, the Syrian border region has become more monitored than ever. President Hassan Rouhani said that "Iran and Russia would continue to cooperate in the Syrian war until the final goal of eradicating terrorism and restoring peace \& security in Syria" (Sanadiki, 2016). It signifies military assistance will continue to provide and supply both countries for the Assad government to achieve security \& peace for Syrian citizens.

The main impact or outcome of the implementation of this policy is the decrease in the wave of Syrian FTF. It confirmed by an intelligence director and a Pentagon operation, Peter Gersten. He estimated every month there 2,000 foreign fighters coming to Syria that crossed the Turkish-Syrian border each month, in 2016 declining to 200 per month (CBS, 2016). FBI's director James Comey, also explained if there are several reasons why this case, namely, in addition to battlefields losses, which most Syria has now ruled by government and its alliance. ISIS has financial problems, thanks to the coalition of airstrikes and other acts that erode millions of dollars from the group's finances. That caused the group to cut the FTF salary by half and even asked its members to pay the electricity bills on the black market with U.S. dollars and people who realized how cruel life is in the ISIS region. ISIS has now suffered heavy pressures from various armed groups, including the assistance of troops from Russia, as well as forces of Syrian and Arab governments. The current alien terrorist fighters to ISIS were once a strong current for thousands of the 
uneducated youths, both women and women gathered in Syria or Iraq, have shrunk in 2016.

\section{Conclusion}

Several individuals join FTFS because they want to find identity, money, status, revenge, justice, some because of ideology, and so on, many young men in western countries whose lives have no purpose, or do not feel like part of their environment. The ISIS group, through her, propagates in a variety of forms, offered to new recruitment or fragile youths To have life and be part of something big when they went to Syria or Iraq. When they go there, they will accept as brothers or sisters who are fighters or heroes.

Syria's defense and security policies in addressing FTF issues are by requesting assistance from Russia and Iran. Syria did this to preserve the security and sovereignty of its country, with the help given by Russia and Iran, it proved to have a significant impact on the Syrian government. It can seem that some towns that were initially ruled by insurgents or opposition are now taken back by governments, such as Palmyra, Homs, Dabiq. With additional troops from Russia and Iran, the Syrian border region became more monitored than ever. The main one is the declining FTF waves in Syria, from the 2,000 FTF, which came to Syria every single one, in the year 2016 decreased to 200 per month. 


\section{BIBLIOGRAPHY}

\section{Book}

Alex P. Schmid, J. T., 2015. Foreign (Terrorist) Fighters with I.S.: A European Perspective.

Hague: International Centre for Counter-Terrorism.

Stein, Theodore. J. 2001. Social Policy and Policymaking by the Branches of

Government and the Public at Large. New York: Columbia University Press.

Schmid, Alex. P., and Judith Tinnes. 2015. Foreign (Terrorist) Fighters with I.S.: A European Perspective. Hague: The International Centre for CounterTerrorism.

\section{Journal}

Byman, D., 2016. ISIS Goes Global. Foreign Affairs: The World Is Flat Surviving Slow Growth, 95(2), 79.

Kashefi, Mahmoud. 2013. The -Arab Spring and its Theoretical Significance: Samuel Huntington_s Theory, -The Clash of Civilizations, Revisited. International Journal of Sociology, 8(2). 1-27.

\section{Internet}

www.aljazeera.com
www.amnesty.org
www.bbc.com
www.cbsnews.com
www.globalo.com
www.ibtimes.com
www.latimes.com
www.nytimes.com
www.reuters.com
www.sana.sy
www.thetimes.co.uk
www.satuharapan.com
www.transparency.org
www.un.org

